\title{
Information and Communication Technologies, Contrasting Teacher - Student Assessments in High Schools within Cuenca, Ecuador
}

\author{
Neli Gonzales ${ }^{\mathrm{a}}$, Janeth Mora ${ }^{\mathrm{b}}$ and César Trelles ${ }^{\mathrm{a}}$ \\ Corresponding author: neli.gonzales@ucuenca.edu.ec \\ aDepartamento de Investigación, Universidad de Cuenca - ECUADOR \\ ${ }^{b}$ Universidad Nacional de Educación - ECUADOR
}

Keywords: treatment; processing information; teach; mathematics

International Journal of Innovation in Science and Mathematics Education, 27(3), 41-54, 2019

\begin{abstract}
The purpose of this study is to diagnose the management and use of Information and Communication Technologies (ICT) as well as mathematical software in the teaching and learning of mathematics. A survey was provided to 64 mathematics teachers from different high schools in the city of Cuenca, Ecuador and their 381 students. A relational research approach was employed to collect and compare the data of the two educational participants, the teacher and the learner. According to the results of the study, most teachers reported that they use ICT to motivate learning and improve the assimilation of concepts. The students however, do not confirm that those technologies are being used at the levels mentioned by their teachers. GeoGebra is a Dynamic Program for the Teaching and Learning of Mathematics. This software is better known and used for teaching in private education than in public education
\end{abstract}

\section{Introduction}

Information and Communication Technologies (ICT) include elements and techniques used in the treatment and processing of information, such as information technology, the Internet, and telecommunications (Suárez, 2010). In a broad context, the telephone, television and computers are part of ICT (Ariel, 2011). On the other hand, the Internet constitutes a set of interconnected and decentralized communication networks of worldwide scope (Balaguer, 2003). At present, the Internet is the most consulted source of information through which any event is disseminated immediately, before other means of communication such as the radio (Noguera, 2012). An element that revolutionised the world around the Internet was instant messaging or 'chat', that is, simultaneous conversation between two or more people in written form through software support and through the network. The chat has been constituted into a new space of daily communicative interaction with its own norms and metalanguages (Sanmartín, 2007). Social networks are another great contribution to the interactive relationships of the network, and they are based on the links that their users have with each other. Facebook was originally created to encourage networking among university students. Twitter, currently one of the most used social applications has not stopped growing since its creation in 2006, with more than 150 million users (Garrido, 2012). 
ICT provides an opportunity to innovate and transform the educational environment. The school of the twentieth century emphasised the learning of technology, but today, the change lies in learning through a mediating technology of personalised learning and oriented to the deployment of methodological skills, such as learning to learn. In turn, ICT would be the foundation of Learning and Knowledge Technologies, whose pedagogy is based on a renewed methodology aimed at the collective creation of knowledge, individualised teaching and active learning through collaboration. The ICT application in teaching processes provides the integration and ability to execute together the personal skills with the knowledge acquired, in order to act effectively in specific situations. The main challenge in this new environment shaped by the information and communication society will be to use ICT within educational environments; while allowing progression in learning. This requires a continuous effort by educators to adapt and to reach an optimal digital competence.

The educational regulations in Europe, North America, and Latin America integrate ICT as a didactic resource in curricular designs from the basic stage to the university. For its part, the Public Administration National Secretariat (LOEI, 2011) in Ecuador, establishes as an obligation of the state "To guarantee digital literacy and information and communication technologies use in the educational process ..." (Chapter 2, Article. 6, letter J.) The curriculum of compulsory education mandated by the Ministry of Education and Culture, 2016, in the field of methodological guidelines states that "information and communication technologies will be part of the habitual use as a facilitating tool for the development of the curriculum." However, to incorporate ICT into the educational process, it is necessary that there be support regarding spaces and physical equipment in such a way that students can access this technology from their own computers, both at home and in the educational institution.

In the information and communication society, teachers are no longer the main source of information, but instead act as guides for students to facilitate their learning through new resources. In this new role teachers support students in taking on a more active role in their own learning, assisting them in becoming inquisitive by creating a more positive relationship with their own learning. Through this process, the student is expected to learn to learn. In this sense, ICT teacher training involves acquiring digital educational competencies that will include, in addition to instrumental digital literacy, a set of knowledge, skills and the practice of educational strategies in the teaching-learning process (Alonso \& Padilla, 2005; Moreira \& Correa Gorospe, 2010). The teacher's mediator action has great importance when selecting reliable and adequate information. Thus, teachers play the role of guides in the processes of research, analysis, selection, interpretation, synthesis and dissemination of information that students can also find available on the Internet. Hence the importance of promoting an adequate initial and permanent teacher training through interaction with different dimensions of ICT (Cabero, 2014). The educator's training must cover areas not only focused on offering technical knowledge of the programs and communication resources of digital networks, but, also on the management of pedagogical and experiential knowledge of what it means to incorporate these technologies into the practice of teaching (Martinez, 2014).

Among the positions in favor of the use of ICT in education, are those that indicate their high motivation power, as well as the fact that there is an increase in interest in tasks. Likewise, they contribute to eliminating the space-time barrier, increasing the student's involvement in school activities, favor collaborative and co-operative work, optimising the students' capacity to express themselves, maximising communication, and improving access to resources from diverse modalities (textual, video, audio) (Cacheiro, 2014). Nevertheless, there are also approaches that warn about possible dangers or disadvantages. García-Valcárcel (2008) and 
Cacheiro (2014) emphasise some of these and in their view, without adequate planning in the teaching-learning process, can lead to significant distraction. Besides, the enormous volume of information from the network can either cause a waste of time when searching for information or a tendency to opt for the first thing that is on the network, giving place to an incomplete and superficial learning, given not all the existing information on the Internet is adapted. This could also lead to the abandonment of other forms of communication. Therefore, both students and teachers require ICT training that allows the potential use of these technologies to be optimal.

One of the most common problems identified by many researchers is the two different versions of ICT used within high schools. According to the Cyprus Education System, $72 \%$ of teachers prepare educational material, $45 \%$ designs lesson plans, and only $35 \%$ use ICT in the classrooms. However, students confirm that less than $15 \%$ of teachers use ICT in the classroom (Vrasidas, 2015). Another study revealed that teachers and students agree with the manner in which ICT could be used, but there is a significant difference in the way that teachers are using ICT. For example, students focus their attention on several possibilities using smartphones, teachers, however, consider smartphones as a distractor with limited possibilities in the learning process (Lindberg, Olofsson, \& Fransson, 2016). In Europe, digitally confident and supportive schools are correlated with digitally confident and supportive students (0.70) much more than digitally supportive schools with digitally confident and supportive teachers $(0.30)$, so the relation between teachers and students with digital educational policies are very important to analyze (Albugami \& Ahmed, 2013).

Livingstone (2011), determined that ICTs are not so embedded in the social practices of everyday life that are taken for granted. Schools demonstrate that they are slower to change their lesson plans than they were to fit the computers in the classroom. García, Basilotta, and López (2014) analysed the data related to the contributions of ICT to collaborative work processes in the classroom from the point of view of teachers in accredited schools with a high level of ICT in the Autonomous Community of Castilla and Leon in Spain. The results indicated that teachers believe that ICT have great potential to improve collaborative activities among students and to develop highly relevant generic skills, although they are also aware of the difficulties faced by both students and teachers in educational practice.

A study in Argentina (Light, Manso, \& Rodriguez, 2010) applied surveys to 847 public high school teachers of the basic areas of English and Technology from Argentina, Chile, Costa Rica and Mexico, observing that the majority of teachers use computers, netbooks or laptops with their students. However, they make a very little use of the more traditional ICT tools and Web 2.0 tools available online. The most commonly used ICT tools are the word processor, the presentation software, and the Internet as a resource for research. Another investigation carried out in Uruguay (Télliz, 2015) addressed ICT didactic use in the good practices for teaching mathematics, revealing that there were few uses of them by teachers from a constructivist perspective for teaching and learning, evidencing the main existence of traditional teaching practices.

In Ecuador, there have been national policies to support the incorporation of ICT, particularly in the teaching of mathematics. Among them are those identified by Martínez et al. (2017) in their report regarding the initial and continuing training of mathematics teachers in Ecuador. Their report indicated that through the SíPROFE program, trainings were offered concerning the introduction of information and communication technologies to mathematics teachers. Similarly, Gonzales, Trelles, and Mora (2017) report on infrastructure support, equipment for classrooms with computer resources, teacher training, creation of educational portals, and 
technical support to schools. Although what is wrong with education cannot be fixed with technology, there is no doubt that modern life is dominated by technology, and the existence of these policies is necessary to avoid staying on the other side of the international digital divide, not proposing policies to integrate ICT in the high school curricula, as Aduwa and Sunday (2005) point out.

Ecuador reports several research works related to the impact of ICT use in mathematics teaching/learning, concluding that ICT have a favorable influence on performance (Flor, 2011), on cognitive development (Párraga, 2016), and on the involvement of students (Yépez, 2012), being more didactic if both teachers and students take part (Castañeda, 2014). Meanwhile, Medina (2015) concluded that there is lack of technological literacy and knowledge about ICT by teachers in an Amazon high school in Zamora province. Teachers lack knowledge about the appropriate use of technologies that could be applicable for the mathematics teaching. In the same line, Amores (2014), investigated ICT use in university classrooms, indicating that from the perception of students, ICT is practically non-existent, and that the traditional way of teaching classes is largely maintained. Thus, virtual classrooms, multimedia equipment or educational software are not used. Gonzales and Trelles (2017) show some of the theoretical foundations and methodological aspects for the mathematical modeling process and the technological resources use in mathematics education. Meanwhile, Illescas, Sánchez, and Gonzales (2016) present positive results in the induction implementation through learning objects, designed specifically as pedagogical mediators, oriented to teach the educational institution's general information regarding the university campus, support services as well as the norms and student rights. Contradictions between teachers and students about the use of ICT for educational development are described in a concrete study by Rivera-Rogel, Ugalde, González, and Salinas (2016) who report that $40 \%$ of teachers indicated that they use ICT for educational purposes, but only $12.1 \%$ of students confirmed this claim, corroborating the assertion of these teachers in that that they took some subjects in high school which used ICT.

\section{Methodology}

This is a non-experimental and quantitative study of descriptive and relational type. The investigation seeks to answer the following questions:

\section{Research questions}

1. What do teachers and students consider as devices employed in mathematics classes?

2. What are the teachers' and students' views about the frequency with which mathematics classes are supported with the use of ICT?

3. What are the teachers' and students' perceptions about the use of specific ICT mathematics classes?

4. Have teachers and students agreed in finding the ICT tools to perform mathematics tasks?

5. Do teachers and students agree on the usefulness of ICT for the teaching-learning process?

6. Is the same level of ICT used for academic purposes by teachers and students in and out of class schedules?

\section{Participants}

The sample was selected by quotas, in terms of institutional support and location area. In total, 23 institutions were chosen (12 public and 11 private, 15 urban [65.2\%] and eight [34.8\%] in urban expansion for convenience. 64 teachers participated: 38 men $(59.3 \%)$ and 26 women (40.6\%); 30 teachers (46.9\%) were professionals in education, 19 of them in mathematics teaching $(29.7 \%$ of the total sample) and $28(43.8 \%)$ were professionals in areas related to 
mathematics, while six $(9.4 \%)$ did not respond to this question. $28.7 \%$ mentioned having a fourth level degree in education. 34 teachers $(53.1 \%)$ work in public institutions and $30(46.9 \%)$ in private institutions, with $34(53.1 \%)$ in urban areas and $30(46.9 \%)$ in areas of expansion. 381 high school students participated, $70.9 \%$ belonging to fiscal institutions, $239(62.7 \%)$ were women and $142(37.3 \%)$ were men. $79.3 \%$ of participants were from the urban area, and $86.4 \%$ of the morning shift.

The surveys were applied in the same institutions both teachers and students separately. Coordinated with the authorities of educational institutions to bring together the participants in a suitable space and be able to apply the same. This process was carried out by research team members as well as staff that was previously qualified for this job. All the institutions, both private and public, have electric service and telephone lines. Two of the 23 institutions do not have a cable local network (LAN). One institution does not have wireless local network, the remainder have broadband.

\section{Information gathering instruments}

A questionnaire was used by the research team which consisted of a first section dedicated to institution informative data (support, location area, working day, number of students), and a second section, composed of 26 items, related to the amount and type of institution resources available (communication technologies, number of students working by computer, subjects that demand to use the computer center, resources accessibility). These were then categorised by level $(1=$ poor, $2=$ good, $3=$ very good, $4=$ optimal $)$, human resources for the ICT area, mechanisms for promoting the ICT incorporation into the teaching-learning process.

The questionnaire included institution and teacher informative data and a section concerning 19 items related to: the equipment type, media and software used by teachers in the mathematics teaching-learning process, frequency of use, degree of mastery and access to computer resources in the institution, type of resources available to the institution, training in ICT management, opinion on the impact of its use in the mathematics teaching-learning process, ICT usefulness in teaching activities and institutional support in terms of incorporating ICT into educational practice. These last items were formulated based on the Likert Scale.

\section{Process}

The collection of information was obtained by applying a questionnaire to the mathematics teachers of both the public and private institutions that were part of the sample. This information was filled by teachers in the same institution, once they obtained the respective permission from the Zone Education Coordination Authorities, and from the institution. The registration form was completed through an interview with the institution's technician.

\section{Data analysis}

SPSS 22 statistical software was used to analyse the results. The Kolmogorov- Smirnov test was conducted for normal distribution in ordinal variables to establish the kind of tests that must be used. Also, the Chi-square test $\left(x^{2}\right)$ was used directly to compare the categorical variables between those of the teachers and students. Two significant different levels to either accept or reject a hypothesis were established: a significant difference at .05 level (*) and a significant difference at .01 level (**). 


\section{Results}

\section{Availability of resources}

Only $17.1 \%$ of the students own a personal computer. Most students share a computer in pairs (76.1\%). The least common cases are those where there is one computer for three or four students, as shown in the number of students per computer below in Table 1.

\section{Table 1: Number of students per computer}

\begin{tabular}{ccl}
\hline Number of computers & Number of Students & $\%$ \\
\hline 1 & 65 & 17.1 \\
2 & 290 & 76.1 \\
3 & 17 & 4.5 \\
4 & 9 & 2.4 \\
Total & 381 & 100 \\
\hline
\end{tabular}

According to students, all the institutions have a computer centre where most of the time (77\%) there are two students working with one computer. In $32.1 \%$ of the cases in state institutions, there is one student per computer, datum verified through observation forms where, indeed, these values are confirmed.

Both teachers and students were asked which resources were allowed to be used in mathematics classes, and significant differences were found among the versions relating to the use of the cell phone, tablet, and computer. According to the first research question regarding the devices employed in classes, there are a considerable number of teachers, above $34 \%$, who assert their use; however, less than $15 \%$ of the students ratify this claim, and even the use of the tablet only reaches $2 \%$. The only device that is fully confirmed by the students is the calculator, in the perception of resources employed in mathematics classes as seen in Table 2.

Table 2: Perception of resources employed in mathematics classes

\begin{tabular}{|c|c|c|c|c|c|c|}
\hline \multirow[b]{2}{*}{ Resource } & \multicolumn{2}{|c|}{ Students } & \multicolumn{2}{|c|}{ Teachers } & \multirow{2}{*}{$\mathrm{x}^{2}(1 \mathrm{gl})$} & \multirow{2}{*}{ p value } \\
\hline & $\mathbf{N}$ & $\%$ & $\mathbf{N}$ & $\%$ & & \\
\hline Cell phone & 53 & 13.9 & 26 & 40.6 & 26.8 & $0.000 * *$ \\
\hline Tablet & 9 & 2.4 & 22 & 34.4 & $86, .6$ & $0.000 * *$ \\
\hline Computer & 55 & 14.4 & 22 & 34.4 & 15.2 & $0.000 * *$ \\
\hline Calculator & 338 & 88.7 & 59 & 92.2 & 0.7 & $0.000 * *$ \\
\hline
\end{tabular}

Note: $\mathrm{x}^{2}(1 \mathrm{gl})=$ Pearson Chi-squared test with 1 degree of freedom

$*$ Significant difference at .05 level $* *$ Significant difference at .01 level

Frequency with which mathematics teachers supported their classes with the use of ICT In Table 3, there is an answer to the second question concerning the differences between teachers and students according to the frequencies that mathematics classes are supported with ICT. The frequency of ICT use in the classroom claimed by teachers and students was compared on a scale from 0 to 5 , where 0 reflects never and 5 reflects every day. Very significant differences were found in this respect. The former obtained a median of 2 , while the median for the latter was 1.5. Table 3 shows the percentages of teachers who affirm that they use the technologies at least once a month. However, although there is a fairly large group of students who maintain that the technologies are used daily, there are also some students who affirm that their teachers never use these resources. 
Table 3: Perceptions of ICT support in mathematics classes

\begin{tabular}{lllllll}
\hline \multirow{2}{*}{ Frequency } & \multicolumn{2}{l}{ Students } & \multicolumn{2}{c}{ Teachers } & \multirow{2}{*}{$\mathbf{~}$} & \multirow{2}{*}{ p value } \\
\cline { 2 - 5 } & $\mathbf{n}$ & $\mathbf{\%}$ & $\mathbf{N}$ & $\mathbf{\%}$ & 0.000 \\
\hline Every day & 157 & 41.2 & 15 & 23.4 & \\
Weekly & 103 & 27 & 25 & 39.1 & \\
Monthly & 27 & 7.1 & 19 & 29.7 & \\
Quarterly & 13 & 3.4 & 3 & 4.7 & 7001.0 & \\
Once during the school year & 14 & 3.7 & 0 & 0.0 & \\
Never & 67 & 15.7 & 2 & 2.1 & \\
Total & 381 & 100 & 64 & 100 & \\
\hline
\end{tabular}

Note: U = Mann-Whitney U Test

$*$ Significant difference at .05 level ** Significant difference at .01 level

\section{ICT management}

Table 4 attempts to answer the third question regarding the use of specific ICT in mathematics classes. When asked to specify what technological tools are more often employed, the students maintained that videos, e-mails, and browsers are the most frequently used $(28.9,26.5 \%$ and $25.5 \%$, respectively), whereas the least used resources are the simulations by mathematical software and the Wikis (6.6 and 3.9\%, respectively). For their part, the teachers stated that they employ videos, browsers, and e-mails. However, differently from what the students claimed, they affirmed that they do it with a very high frequency $(79.7,78.1$ and $70.3 \%$, respectively). Conversely, they said that what they use the least are the wikis (26.6\%). Evidently, there is a very clear disagreement between what the teachers and the students pointed out (significant difference at .01 level in all cases). The teachers maintained that they do use those resources, but in no case was it confirmed by what the students said.

Browsers, e-mails, and videogames are employed with a $50 \%$ frequency; virtual platforms with an average of $20 \%$ frequency; while wikis and blogs are just used in a $10.0 \%$.

Table 4: Use of ICT in mathematics classes

\begin{tabular}{lllllll}
\hline & \multicolumn{2}{l}{ Students } & \multicolumn{2}{l}{ Teachers } & \multicolumn{1}{c}{$\begin{array}{l}\mathbf{x}^{\mathbf{2}} \\
\mathbf{( 1 ~ g l )}\end{array}$} & p value \\
\hline Resource & $\mathbf{n}$ & $\mathbf{\%}$ & $\mathbf{N}$ & $\mathbf{\%}$ & & \\
\hline Virtual Platforms & 89 & 23.4 & 26 & 40.6 & 8.5 & $0.004^{* *}$ \\
Wikis & 15 & 3.9 & 17 & 26.6 & 42.0 & $0.000^{* *}$ \\
Blogs & 60 & 15.7 & 26 & 40.6 & 21.8 & $0.000^{* *}$ \\
Simulations by mathematical software & 25 & 6.6 & 39 & 60.9 & 131.8 & $0.000^{* *}$ \\
Learning objects & 88 & 23.1 & 33 & 51.6 & 22.4 & $0.000^{* *}$ \\
PP and/or Prezi Presentations & 88 & 23.1 & 43 & 67.2 & 51.3 & $0.000^{* *}$ \\
Videos & 110 & 28.9 & 51 & 79.7 & 61.28 & $0.000^{* *}$ \\
Didactic Guides & 68 & 17.8 & 43 & 67.2 & 71.3 & $0.000^{* *}$ \\
Browsers & 97 & 25.5 & 50 & 78.1 & 68.7 & $0.000^{* *}$ \\
Social Networks & 54 & 14.2 & 28 & 43.8 & 31.9 & $0.000^{* *}$ \\
E-mail & 101 & 26.5 & 45 & 70.3 & 47.7 & $0.000^{* *}$ \\
\hline
\end{tabular}

*Significant difference at .05 level ** Significant difference at .01 level

\section{Frequency of ICT use in the teaching-learning process (scale between 0 and 4)}

Table 5 demonstrates that there are differences in students and teachers regarding their beliefs about the usage of the tools employed within the classroom to perform mathematics tasks. The median test was applied in order to facilitate the analysis of the scale. Table 5 shows the values higher than the median, which in all cases, except for the word processor, was 1 . In this sense, the frequencies (n) that are shown respond to those cases where resources are indeed employed even if only a few times. From the students' perspective, the most employed resources are PowerPoint presentations, spreadsheets, and word processors (36.2, 24.4 and 27.0\%, 
respectively); however, according to the teachers' criteria, these resources are used more frequently, and they point out that spreadsheets and presentation software are employed at least 90.6 and 84.4\%, respectively. The next resources used are GeoGebra and Word Processor (71.9 and $70.3 \%$ ) by private education much more than by public education ( 27 and $18.6 \%$ ). The least used resources, according to the students, are Graphmatica, Autograph, Mathematica WI, Derive 6, Mathematica W, Cabri Geometry, Ti-Nspire CAS, Matlab, Winplot, and Quiz Faber, all of which have a level of use lower than $10 \%$. According to the teachers, the least used programs are above the $10 \%$ but below $20 \%$, and refer specifically to Mathematica W, Mathematica WI, Algebrator, Ti-Nspire CAS, Quiz Faber and Autograph. It is worth mentioning that the use of Algebrator is the only one with similar appreciations by both teachers and students (see Table 5).

Table 5: Tools employed to perform mathematic tasks

\begin{tabular}{|c|c|c|c|c|c|c|}
\hline \multirow[b]{2}{*}{ Resource } & \multicolumn{2}{|c|}{ Students } & \multicolumn{2}{|c|}{ Teachers } & \multirow{2}{*}{ Med. $^{a}$} & \multirow{2}{*}{$p$ value } \\
\hline & $\mathbf{n}$ & $\%$ & $\mathbf{N}$ & $\%$ & & \\
\hline Word Processor & 103 & 27.0 & 45 & 70.3 & 2 & $0.000 * *$ \\
\hline Spreadsheet & 131 & 34.4 & 58 & 90.6 & 1 & $0.000 * *$ \\
\hline Power Point Presentations & 138 & 36.2 & 54 & 84.4 & 1 & $0.000 * *$ \\
\hline Derive 6 & 15 & 3.9 & 23 & 35.9 & 1 & $0.000 * *$ \\
\hline Geogebra & 71 & 18.6 & 46 & 71.9 & 1 & $0.000 * *$ \\
\hline Graphmatica & 24 & 6.3 & 20 & 31.3 & 1 & $0.000 * *$ \\
\hline Winplot & 9 & 2.4 & 15 & 23.4 & 1 & $0.000 * *$ \\
\hline Matlab & 9 & 2.4 & 20 & 31.3 & 1 & $0.000 * *$ \\
\hline Cabri Geometry & 14 & 3.7 & 13 & 20.3 & 1 & $0.000 * *$ \\
\hline Mathematica WI & 18 & 4.7 & 11 & 17.2 & 1 & $0.000 * *$ \\
\hline Mathematica W & 15 & 3.9 & 12 & 18.8 & 1 & $0.000 * *$ \\
\hline Quiz Faber & 6 & 1.6 & 8 & 12.5 & 1 & $0.000 * *$ \\
\hline Ti-Nspire CAS & 10 & 2.6 & 9 & 14.1 & 1 & $0.000 * *$ \\
\hline Algebrator & 44 & 11.5 & 10 & 15.6 & 1 & 0.112 \\
\hline Autograph & 22 & 5.8 & 7 & 10.9 & 1 & $0.039 *$ \\
\hline
\end{tabular}

Note: The original scale is from 0 to 4 points where 0 means that it never occurs and 5 means always. Values equal or lower than the median are not reported but only those that are above it.

Med. ${ }^{\mathrm{a}}=$ Median

$*$ Significant difference at .05 level ** Significant difference at .01 level

As indicated in Table 6 below, the situation of public and private institutions has been compared and it has been found that there are similarities in the use of the word processor and the spreadsheet, which is around 40\% -50\% in both types of institutions, as well as in the limited use of Ti-Nspire CAS, Algebrator and Autograph, which barely approximates a 10\%. Nevertheless, private institutions have evident advantages in the use of multimedia projectors for Power Point presentations with a 63.9\%, while public institutions use them in just a $43.6 \%$. An actual mathematical resource is Geogebra, which has a $45.4 \%$ of use in private institutions and $23.7 \%$ in public ones, a difference that is also considered significant. It was found that the teachers who use ICT tools are, in their majority, professionals in the field of education or mathematical education. Therefore, the training of the teachers in charge of the classrooms directly affects the use of ICT in educational institutions. 
Table 6: Tools employed to perform mathematics tasks in public and private institutions

\begin{tabular}{|c|c|c|c|c|c|c|}
\hline \multirow[b]{2}{*}{ Resource } & \multicolumn{2}{|c|}{ Public Education } & \multicolumn{2}{|c|}{ Private Education } & \multirow{2}{*}{ Med. $^{\mathrm{a}}$} & \multirow{2}{*}{$p$ value } \\
\hline & $\mathbf{n}$ & $\%$ & $\mathbf{N}$ & $\%$ & & \\
\hline Word Processor & 93 & 35.0 & 55 & 46.2 & 2 & 0.064 \\
\hline Spreadsheet & 122 & 45.9 & 67 & 56.3 & 1 & 0.107 \\
\hline PowerPoint Presentations & 116 & 43.6 & 76 & 63.9 & 1 & $0.000 * *$ \\
\hline Derive 6 & 16 & $6, .0$ & 22 & 18.5 & 1 & $0.000 * *$ \\
\hline GeoGebra & 63 & 23.7 & 54 & 45.4 & 1 & $0.000 * *$ \\
\hline Graphmatica & 23 & 8.6 & 21 & 17.6 & 1 & $0.014^{*}$ \\
\hline Win plot & 12 & 4.5 & 12 & 10.1 & 1 & 0.055 \\
\hline Matlab & 13 & 4.9 & 16 & 13.4 & 1 & $0.006^{* *}$ \\
\hline Cabri Geometry & 12 & 4.5 & 15 & 12.6 & 1 & $0.007 * *$ \\
\hline Mathematica WI & 15 & 5.6 & 14 & 11.8 & 1 & 0.051 \\
\hline Mathematica W & 14 & 5.3 & 13 & 10.9 & 1 & $0.072 * *$ \\
\hline Quiz Faber & 5 & 1.9 & 9 & 7.6 & 1 & $0.013^{*}$ \\
\hline Ti-Nspire CAS & 10 & 3.8 & 9 & 7.6 & 1 & 0.177 \\
\hline Algebrator & 36 & 1.5 & 18 & 15.1 & 1 & 0.802 \\
\hline Autograph & 16 & 6.0 & 13 & 10.9 & 1 & 0.139 \\
\hline
\end{tabular}

Note: The original scale is from 0 to 4 points where 0 means that it never occurs and 4 means always. The values equal or lower than the median are not reported but only those that are above it.

Med. $^{\mathrm{a}}=$ Median $*$ Significant difference at .05 level $* *$ Significant difference at .01 level

\section{Functionality of ICT in the teaching-learning process (scale from 0 to 4)}

The next question was concerning students' and teachers' points of view regarding the usefulness of ICT to the learning process. The median, except for allowing a fast search of information, was placed in a value of 3 , equivalent to important. Both teachers and students agree that the technological resources are very important mechanisms to search information with greater speed. At least $40 \%$ of the students maintain that these resources improve the assimilation of concepts, strengthen the capacity for mental calculations, and facilitate the reasoning processes. The teachers have a similar point of view as over $40 \%$ point out that these resources motivate the acquisition of new knowledge and facilitate the reasoning processes. Nevertheless, few teachers affirm that these resources promote academic honesty (17.2\%). As indicated by Table 7 , teachers and students disagree regarding reliable information, academic honesty, and strengthening of mental calculation.

Table 7: ICT usefulness for the teaching/learning process

\begin{tabular}{lllllll}
\hline & \multicolumn{2}{l}{ Students } & \multicolumn{2}{l}{ Teachers } & \multirow{2}{*}{ Med. $^{\text {a }}$} & \multirow{2}{*}{ p value } \\
\hline Resource & $\mathbf{n}$ & $\mathbf{\%}$ & $\mathbf{N}$ & $\mathbf{\%}$ & & \\
\hline Motivate acquisition of new knowledge & 155 & 40.7 & 28 & 43.8 & 3 & 0.669 \\
Allow faster search for information & 0 & 0.0 & 0 & 0.0 & 4 & - \\
Improve assimilation of concepts & 169 & 44.4 & 23 & 35.9 & 3 & 0.248 \\
Facilitate reasoning processes & 161 & 42.3 & 26 & 40.6 & 3 & 0.921 \\
Present reliable information & 103 & 27,0 & 25 & 39.1 & 3 & $0.045^{*}$ \\
Promote academic honesty & 132 & 34.6 & 11 & 17.2 & 3 & $0.011^{* *}$ \\
Strengthen capacity for mental calculation & 167 & 43.8 & 15 & 23.4 & 3 & $0.009^{* *}$ \\
\hline
\end{tabular}

Note: The original scale is from 0 to 4 points, where 0 means that it is not important and 4 means that it is very important. Values equal to or lower than the median are not reported but only those that are above it.

Med. ${ }^{\mathrm{a}}=$ Median

\section{ICT used to communicate in out of class schedules}

Lastly, the question regarding the use of ICT in out of class schedules for academic purposes was addressed. Table 8 below indicates that from the students' point of view, teachers 
communicate with students through the virtual platform $21 \%$ of the time. However, $71.9 \%$ of teachers say that their communication outside the classroom is through this platform. Another resource that is frequently used, according to the teachers, are Wikis at $45.3 \%$. Nevertheless, in the students' opinion, they are employed in a percentage of 18.45 . Blogs receive a relevant role in both cases, but social networks are only given a $23.4 \%$ of frequency by the teachers and are barely mentioned by the students.

Table 8: ICT employed in out of class schedules

\begin{tabular}{|c|c|c|c|c|c|c|}
\hline \multirow[b]{2}{*}{ Resource } & \multicolumn{2}{|c|}{ Students } & \multicolumn{2}{|c|}{ Teachers } & \multirow{2}{*}{$\begin{array}{l}x^{2} \\
(1 \mathrm{gl})\end{array}$} & \multirow{2}{*}{ p value } \\
\hline & n & $\%$ & $\mathbf{N}$ & $\%$ & & \\
\hline Virtual platforms & 54 & 14.2 & 20 & 31.3 & 11.5 & $0.001 * *$ \\
\hline Wikis & 6 & 1.6 & 9 & 14.1 & 2.62 & $0.000 * *$ \\
\hline Blogs & 18 & 4.7 & 15 & 23.4 & 27.9 & $0.000 * *$ \\
\hline Social Networks & 70 & 18.4 & 29 & 45.3 & 23.0 & $0.000 * *$ \\
\hline E-mail & 80 & 21.0 & 46 & 71.9 & 69.9 & $0.000 * *$ \\
\hline PP and/or Prezi Presentations & 2 & 0.5 & 3 & 4.7 & $5.201^{\mathrm{a}}$ & $0.000 * *$ \\
\hline
\end{tabular}

${ }^{a}$ In this case, the Correction by Continuity was employed.

*Significant difference at .05 level ** Significant difference at .01 level

\section{Conclusion}

The Internet network is present in $100 \%$ of the educational institutions in Cuenca's urban area and those in urban expansion, which participated in the study, a situation that ratifies it as a global communication network (Balaguer, 2003). Approximately $70 \%$ of mathematics teachers make use of information search engines, confirming them as the most consulted source of information (Noguera, 2012). $79 \%$ of teachers say that they use videos, but only $28.9 \%$ of their students confirm their use. Teachers also say that they use e-mail in $70.3 \%$ cases to communicate with their students out of class, but the results of the students show that only $26.6 \%$ of teachers use e-mail to communicate out of class. $43.8 \%$ of the teachers and $14.2 \%$ of the students say that they use social networks; consequently, chat, Facebook and Twitter have not yet reached, among teachers and students, the employment frequency that has reached among other users (Garrido, 2012). This low percentage of use may be due to controversial opinions, regarding the use of social networks, particularly Facebook, since in the research by Cassany and Llach (2017), there are two groups of teachers, some who refuse to use them for educational purposes and others who take advantage of them for formal teaching activities; or as García and González (2017) point out in their research on personal learning environments, there is a great ignorance of resources, considering that teachers need to leave their comfort space of the known and be incorporated into a training process so that they acquire new strategies and create scaffolds that allow their students to develop and manage their personal learning environments.

Approximately half of the participating institutions have equipped the computer centers. A quarter of them acquired equipment, spare parts and technological accessories in the last year, and in a third of the schools, teaching staff were assigned to work with ICT. The classrooms equipped with projectors and computers are the resources with the greatest access in schools, regardless of the number of students they hold and the type of support, which implies that the educational authorities of the public and private sector are aware of the need to provide equipment and resources for their institutions. This would help to ensure digital literacy and ICT use in the educational process (LOEI, 2011). However, it was determined that institutions in general should not have wikis, and the percentage of teachers using blogs and virtual platforms should not exceed $8 \%$ and $13 \%$ respectively. 
The most used software by mathematics teachers are word processors, spreadsheets, and presentation software, data that matches those found in Argentina in a study involving 847 teachers (Light, Manso, \& Rodriguez, 2010), where one of the conclusions states that the most used tools by teachers are the word processor, the presentation software, and the use of the Internet. In Ecuador, a study of 365 teachers in the areas of social science, natural science, English and mathematics in basic and high school general education, Gonzales, Trelles, and Mora (2017) confirm that teachers use these same tools and do so fundamentally for teacher management. Although Geogebra is rarely used, it is the most used mathematical software. The specific ones like Derive 6, Winplot and video maker software are little used by the teachers. In this sense, it could be assumed that there is a lack of technological literacy and knowledge about ICT use in mathematics teaching (Medina, 2015). These results could be interpreted depending on the level of access to computers and the Internet, since both public and private institutions handle a good level of access. However since most computers are in classrooms or computer labs, students need permission and teacher management to use them, as Samuelsson (2010) points out in his research on ICT use in Sweden with 256 young people aged 13. The results indicate that although all children use ICT, the highest degree of use is for entertainment and socialisation and not for educational purposes, as there is a lack of basic computer skills and seriousness as a tool for education and learning (Samuelsson, 2010).

According to the teachers' self-assessment, the mastered resources are: electronic mail, information search engines, word processor, and information handling on removable disks, presentation software, and spreadsheets. In all these cases, the level of proficiency is qualified as "very good", but not in the domain in the handling of mathematical software, which is categorized as "deficient" and "good". It was found that teachers with training in education or mathematics education use ICT more frequently than teachers with training in the area of engineering or related careers. In addition, direct relationships, of medium and high intensity were found between the management domain and the frequency of use of resources of office automation and mathematical software use (except: winplot, matlab, and mathempatica). This relationship would be a possible causal variable between the resource frequency of use and the domain level. Thus, the tools teachers use most frequently are the ones they master, which coincides with the study of García and González (2017).

It is necessary and urgent that Ecuador gets totally involved in the access to technology, complying with what is stated in the LOEI about guaranteeing digital literacy. It is also essential to implement criteria guidelines for teacher selection, as well as training, pedagogical up-dating, and monitoring of teacher use of the technological tools, so that besides guaranteeing time reduction in the learning processes, the use of ICT becomes an agent for change in the teaching paradigm. Finally, we consider that the teaching of mathematics requires effective instructors who are really good mathematicians and completely functional in the pedagogical use of mathematical software in order to conceptualize and visualize the problems and reduce the time for their solution.

ICTs are qualified, by teachers, as highly useful in the information search, preparation of work guides and curricular planning; moderately useful in the development of evaluation activities and supporting the classes' development. Additionally, they consider that ICTs extend the teachers knowledge, promote their training, facilitate the explanation of reasoning processes, present reliable information, and allow a quick information search, aspects related to teaching management that would complement the educational competences and correspond to the set of knowledge, skills and practice of educational strategies in the teaching-learning process (Alonso \& Padilla, 2005; Moreira \& Correa Gorospe, 2010). However, they do not respond to 
the mediating role of today's teacher, hence the need to develop ongoing training programs not only in instrumental digital literacy, but in the management of pedagogical knowledge of how to incorporate ICT in the mathematics teaching.

Regarding the ICT impact in education, more than $80 \%$ of teachers rate it as effective and significant as an incentive in student research, in strengthening group work and encouraging debate, which would imply greater involvement of students, as Yepes concludes in his study (2012). Around $40 \%$ of the students and teachers, without significant differentiation, assert that the ICT improve the assimilation of concepts, motivate the acquisition of knowledge, and improve academic presentations, that is, they coincide with the positions in favor of ICT use in education indicated by Cacheiro (2014).

Approximately half of teachers point out that ICT affect insignificantly or weakly the promotion of academic honesty, a disadvantage different from those cited by García - Valcárcel (2008) and Cacheiro (2014); or as Calm et al. (2017) conclude, there is greater job satisfaction of both students and teachers with the handling of questionnaires in wiris, as well as a new paradigm of formative evaluation, with instantaneous feedback. Finally, it was found that there is greater access to ICT in private schools than in public schools, and also that a greater percentage of private institutions have computer resources, such as learning management systems LMS platform, institutional informative website for information or educational purposes, institutional blogs, among others. To this, a greater percentage of private institutions that use social networks is added, and a greater proficiency was reported in teachers of particular institutions in mathematical software, such as Derive 6, GeoGebra, Graphamatica and Matlab.

It is important to mention that there are different points of view regarding the diffusion of ICT in High Schools. Teachers consider that they use them much more often than the students confirmed, which settles what Vrasidas (2015), Lindberg, Olofsson, and Fransson (2016), Rivera-Rogel et al. (2016) said in their studies.

\section{Acknowledgements}

This document is the result of a part of the Modeling project with free software support and changes in learning processes in mathematics in middle school students. The following organisations contributed funds and/or support to this Project:

- Ministry of Education through the Zonal Coordination 6 - ECUADOR

- Research Department of the University of Cuenca - ECUADOR

- Faculty of Philosophy of the University of Cuenca - Ecuador

\section{References}

Aduwa, S., \& Sunday, E. (2005). Using information and communication technology in secondary schools in Nigeria: Problems and prospects. Educational Technology \& Society. 8(1), 104-112.

Agyei, D., \& Voogt, J. (2011). ICT use in the teaching of mathematics: Implications for professional development of pre-service teachers in Ghana. Education and Information Technologies, 16, 423-439. doi:10.1007/s10639-010-9141-9.

Albugami, S., \& Ahmed, V. (2013). Success factors for ICT implementation in Saudi secondary schools: From the perspective of ICT directors, head teachers, teachers and students, 11 (1), 36-54.

Alonso, C., \& Padilla, L. (2005). Aplicaciones educativas de las tecnologías de la información y la comunicación. Madrid, España: Ministerio de Educación y Ciencia.

Amores, A. (2014). Impacto del uso y aplicación de las TIC en el proceso de enseñanza y aprendizaje de la matemática de los estudiantes del primer semestre de la carrera de matemática y física de la Facultad de Filosofía de la Universidad Central del Ecuador. Retrieved from http://www.dspace.uce.edu.ec/bitstream/25000/3270/1/T-UCE-0010-596.pdf. 
Ariel, C. (2011). Nociones de Cibercultura y Periodismo. Buenos Aires: Lulu.com.

Balaguer, R. (2003). Internet: un nuevo espacio psicosocial. Montevideo, Uruguay: Ediciones Trilce.

Cabero, J. (2014). Formación del profesorado universitario en TIC. Aplicación del método Delphi para la selección de los contenidos formativos. Educación XX1, 17(1), 111-132. doi:http://dx.doi.org/10.5944/educxx1.17.1.10707

Cacheiro, M. (2014). Educación y tecnología: Estrategias didácticas para la integración de las TIC (Primera ed.). Madrid: UNED.

Calm, R., Masià, R., Olivé, C., Parés, N., Pozo, F., Ripoll, J., \& Sancho, T. (2017). Use of wiris quizzes in an online calculus course. Journal of Technology and Science Education.

Cassany, D., \& Llach, S. (2017). La digitalización del aula de ciencias: creencias y prácticas. Digital Education, (31), 93-115.

Castañeda, D. (25 de Junio de 2014). El uso de recursos TIC de matemática y su relación con el rendimiento académico en matemátuca de los estudiantes del primer curso de bachillerato general unificado del Colegio Menor Universidad Central del Ecuador. Retrieved from http://www.dspace.uce.edu.ec/bitstream/25000/3569/1/T-UCE-0010-621.pdf.

Flor, M. (Mayo de 2011). Los Objetivos de Aprendizaje, como Recursos Didácticos Mediados por Tecnología, en el Aprendizaje Signifcativo de Matemáticas. Retrieved from https://repositorio.itesm.mx/ortec/bitstream/11285/570382/1/DocsTec_11302.pdf.

García, A., Basilotta, P., \& López, C. (2014). ICT in collaborative learning in the classrooms of primary and secondary education. Comunicar Journal, 21, 65-74. Retrieved from http://www.revistacomunicar.com/indice-en/articulo.php?numero=42-2014-06.

García, J., \& González, M. (2017). Entornos personales de aprendizaje de estudiantes universitarios costarricenses de educación: análisis de las herramientas de búsqueda de información. Revista Electrónica de Investigación Educativa, 35(2), 389-409.

García-Valcárcel, A. (2008). Investigación y tecnologías de la información y comunicación al servicio de la innovación educativa. Salamanca, España: Ediciones Universidad Salamanca.

Garrido, A. (2012). Twitter. Redes sociales en educación. Obtenido de Introducción: http://twitter.antoniogarrido.es/introduccin.html.

Gonzales, N., \& Trelles, C. (2017). La modelación con apoyo de software libre y los cambios en los procesos de aprendizaje en matemáticas en los estudiantes de primero de bachillerato. Revista Educación y Desarollo Social.

Gonzales, N., Trelles, C., \& Mora, J. (2017). Manejo Docente de las Tecnologías de la Información y Comunicación. INNOVA Research Journal, 2(4), 61-72. doi:ISSN 2477-9024.

Illescas, L., Sánchez, M., \& Gonzales, N. (2016, October). Assessing the impact of learning objects in an induction process applied to students of the University of Cuenca. In 2016 XI Latin American Conference on Learning Objects and Technology (LACLO) (pp. 1-9). IEEE.

Light, D., Manso, M., \& Rodriguez, C. (2010). Encuesta internacional para docentes sobre el uso de la tecnología para la enseñanza: Resultados preliminares de América Latina. En J. Sánchez (Ed.), Congreso Iberoamericano de Informática Educativa, 1, págs. 390-396. Santiago de Chile. Retrieved from http://www.costadigital.cl/noticias/encuesta tic.pdf.

Lindberg, J O., Olofsson, A D., Fransson, G. (2016). The Proceedings of the International Conference on Information Communication Technologies in Education 2016, 11.

Livingstone, S. (2012). Critical reflections on the benfits of ICT in education. Oxford Review of Education, $38(1), 9-24$. Retrieved from

http://eprints.lse.ac.uk/42947/1/ libfile repository_Content_Livingstone, \%20SCritical\%20reflections_Liv ingstone_Critical\%20reflections_2014.pdf.

LOEI. (2011). Ley Orgánica de Educación Superior. Ecuador. Retrieved from http://diccionario.administracionpublica.gob.ec/adjuntos/2loei.pdf.

Martinez, A. (2014). Curso-taller para docentes de educación primaria sobre Tecnologías de la Información y la Comunicación, factor de aprendizajes significativo en los alumnos. UNIVERSIDAD PEDAGÓGICA NACIONAL, 97.

Martínez, M., Castillo, P., Trelles, C., Gonzales, N., Calle, E., Ayala, A., . . Flores, M. (2017). Informe sobre la formación inicial y continua de profesores de matemáticas en el Ecuador. Cuadernos de Investigación y Formación Educación Matemática, 12(12), 11-45.

Medina, M. (2015). La alfabetización tecnológica y su incidencia en la aplicación de las TIC para el desarrollo del proceso de enseñanza - aprendizaje de la matemática en el Colegio Fiscomisional Ecuador Amazónico de la parroquia El Pangui, cantón El Pangui. Retrieved from https://dspace.unl.edu.ec/jspui/bitstream/123456789/16354/1/TESIS\%20IMPRESION\%20manuel\%20ferna ndo\%20chalan.pdf. 
Ministerio de Educación y Cultura [MINEDUC]. (2016). MINEDUC. Introduccion-General.pdf. Retrieved from, de https://educacion.gob.ec/: https://educacion.gob.ec/wpcontent/uploads/downloads/2016/03/Introduccion-General.pdf.

Moreira, A.M., \& Correa Gorospe, J. (2010). Las TIC entran en las escuelas. Nuevos retos educativos, nuevas prácticas docentes. En J. de Pablos, M. Area, J. Valverde, \& J. Correa, Políticas educativas y buenas prácticas con TIC (págs. 43-80). Barcelona, España: Graó.

Noguera, J. (2012). Redes y periodismo: Cuando las noticias se socializan (1 $\left.{ }^{\mathrm{a}} \mathrm{ed}.\right)$. Barcelona, España: Editorial UOC.

Párraga, P. (2016). Las TIC en el proceso de enseñanza-aprendizaje de matemática para estudiantes de segundo año de educación general básica. Retrieved from http://repositorio.pucese.edu.ec/bitstream/123456789/646/1/PARRAGA\%20TREJO\%20PEDRO\%20WAG NER.pdf.

Rivera-Rogel, D., Ugalde, C., González, C., \& Salinas, G. C. (2016). Uso que profesores y estudiantes ecuatorianos dan a las Tecnologías de la Información y la Comunicación. Revista ESPACIOS | Vol. 37 (No 33) Año 2016. Retrieved from http://www.revistaespacios.com/a16v37n33/16373302.html.

Samuelsson, U. (2010). ICT use among 13 year old Swedish children. Learning, Media and Technology, 35(1), 15-30.

Sanmartín, J. (2007). El chat: la conversación tecnológica. Madrid, España: Arco Libros.

Suárez, R. (2010). Tecnologías de la Información Y la Comunicación. Editorial S.L.

Télliz, F. (2015). Uso didáctico de las TIC en las buenas prácticas de enseñanza de las matemáticas. Estudio de las opiniones y concepciones de docentes de educacióin secundaria en el departamento de Artigas. Cuadernos de Investigación Educativa, 6(2), 13-31. Retrieved from http://www.scielo.edu.uy/pdf/cie/v6n2/v6n2a02.pdf

Vrasidas, C. (2015). The rhetoric of reform and teachers' use of ICT. British Journal of Educational Technology, 46(2), 370-380. https://doi.org/10.1111/bjet.12149

Yépez, J. (2012). Propuesta de una nueva metodología utilizando TIC's para el aprendizaje de matemática en el Segundo de bachillerato especialidad Contabilidad de la Unidad educativa "Rincón del Saber". Retrieved from http://www.dspace.uce.edu.ec/bitstream/25000/1874/1/T-UCE-0010-262.pdf 